\title{
Study on the Influence and Optimization of the Venturi Effect on the Natural Ventilation of Buildings in the Xichang Area
}

\author{
Lili Zhang *, Lei Tian (D, Qiong Shen, Fei Liu, Haolin Li, Zhuojun Dong, Jingyue Cheng, Haoru Liu \\ and Jiangjun Wan
}

check for

updates

Citation: Zhang, L.; Tian, L.; Shen, Q.; Liu, F.; Li, H.; Dong, Z.; Cheng, J.; Liu, H.; Wan, J. Study on the Influence and Optimization of the Venturi Effect on the Natural Ventilation of Buildings in the Xichang Area. Energies 2021, 14, 5053. https://doi.org/10.3390/en14165053

Academic Editor: Efstathios

E. Michaelides

Received: 28 June 2021

Accepted: 12 August 2021

Published: 17 August 2021

Publisher's Note: MDPI stays neutral with regard to jurisdictional claims in published maps and institutional affiliations.

Copyright: (c) 2021 by the authors. Licensee MDPI, Basel, Switzerland. This article is an open access article distributed under the terms and conditions of the Creative Commons Attribution (CC BY) license (https:// creativecommons.org/licenses/by/ $4.0 /)$.
College of Architectural and Urban-Rural Planning, Dujiangyan Campus, Sichuan Agricultural University, Ya'an 611830, China; tianlei@stu.sicau.edu.cn (L.T.); swydong@sicau.edu.cn (Q.S.); 79013@sicau.edu.cn (F.L.); 2020225001@stu.sicau.edu.cn (H.L.); 2020325009@stu.sicau.edu.cn (Z.D.); chengjingyue@stu.sicau.edu.cn (J.C.); liuhaoru@stu.sicau.edu.cn (H.L.); wanjiangjun@sicau.edu.cn (J.W.)

* Correspondence: 41414@sicau.edu.cn; Tel.: +86-18-280-215-370

\begin{abstract}
Natural ventilation is a way to reduce the energy consumption of building operations and improve the indoor living environment comfort. The venturi cap is designed with a roof, grille and wind deflector to intensify the natural ventilation of buildings. The structural parameters of the venturi cap were designed using an orthogonal design. Fluid analysis software was used for numerical simulation, and variance analysis was used to study the importance of seven influence factors: the width of the roof opening, the roof slope, the height of the wind deflector, the horizontal width of the wind deflector, the angle of the wind deflector, the angle of the grille, and the spacing of the grille slices. The results show that the most significant influencing factor is the width of the roof opening, while significant influence factors include the angle of the grille and the horizontal width of the wind deflector. Additionally, the optimum parameter combination for ventilation performance at the research level was put forward, with the proposed combination achieving a volume flow rate of $5.507 \mathrm{~m}^{3} / \mathrm{s}$. The average temperature of the horizontal plane at a height of $1.2 \mathrm{~m}$ above the ground was $3.002 \mathrm{~K}$ lower than that without a venturi cap, which provides a reference for the optimization of indoor ventilation design in buildings in the Xichang area.
\end{abstract}

Keywords: natural ventilation; venturi effect; orthogonal design; numerical simulation; variance analysis

\section{Introduction}

\subsection{The Necessity of Natural Ventilation}

The construction industry has been identified as one of the most energy-intensive industries, accounting for about $42 \%$ of global energy consumption [1]. The total energy consumption of residential buildings accounts for $18 \%$ of the energy consumption in the construction industry, and is growing at a rate of $1.5 \%$ each year [2]. Natural ventilation offers great potential with respect to the energy efficiency of buildings. One of the main measures employed to achieve indoor comfort while mitigating building energy consumption is the strengthening of natural indoor ventilation [3]. The results reported in [4] suggest that the amount of energy saved using other ventilation modes is not high, representing only $0.03 \%$ of common natural ventilation. That is to say, the application of technology to enhance the efficiency of natural ventilation in buildings without an external environment is a way of saving energy in buildings [5]. In the construction industry, building ventilation is one of the most important parameters to be considered in order to maintain a comfortable indoor environment and to provide better indoor air quality [6]. According to research reported by Canada's Environmental Defense Organization, 68\% of human diseases are caused by indoor air pollution [7]. The best way to improve indoor air quality is to allow enough fresh air into the building and ensure that there is a reasonable air distribution inside the building [8]. In addition, the outbreaks of sick building syndrome (SBS) in developed countries in the 1970s and 1980s, severe acute respiratory syndrome coronavirus 
(SARS) in Asia in 2003, and Corona Virus Disease 2019 (COVID-19) that has been sweeping the world since late 2019 have led people to think deeply about the safety and health of their offices and living spaces, with suitable temperature and humidity being achieved in enclosed spaces by mechanical means in modern architecture.

The total wind energy resource reserves of China at the height of $10 \mathrm{~m}$ above the ground are about 4.35 billion KW, which ranks first in the world [9]. Considering the abundance of wind energy resources, land use types, and landforms, and the variability of wind energy, the regions with the most abundant sources of wind energy are the Tibet Plateau, the Hexi Corridor, and Inner Mongolia [10]. Xichang is located on the Anning River Plain of the Western Sichuan Plateau, which has the best wind resources in Sichuan Province. The buildings in Xichang pay special attention to the ventilation of the building, while little attention is paid to the performance of thermal insulation, which has little impact on the residents' living situation [11]. Using a venturi cap to optimize ventilation reduces energy consumption and improves the ventilation conditions in the Xichang area, meeting the needs of residents on an environmentally sustainable basis.

\subsection{Venturi Cap}

The venturi effect is an application of natural ventilation that can be employed in both horizontal and vertical directions. Vertical applications (Figure 1) are implemented in the form of a venturi cap. Most local buildings in Xichang have sloped roofs, which also meet the structural requirements of venturi caps. As shown in Figure 1, the main structure of the venturi cap comprises a sloping roof, a wind deflector, and a grille. The sloping roof guides the airflow separated at the windward facade to the roof ridge, making it accelerate, forming negative pressure at the openings, where the negative pressure causes the indoor air to be sucked out. The addition of a wind deflector on the upper side of the roof ridge can form a complete "venturi tube" structure, which can collect more incoming outdoor air and reduce the cross-section, enhancing the acceleration effect and increasing the adsorption capacity. (Figure 2) The grille blocks out direct sunlight, reducing heat radiation in the summer and preventing small animals from falling through the openings. The grille can also be closed if necessary. While protecting traditional culture, making full use of renewable resources to create comfortable indoor environments is an indispensable part of the protection and renewal of residential buildings. It is also one of the crucial solutions for building energy conservation and emission reduction.

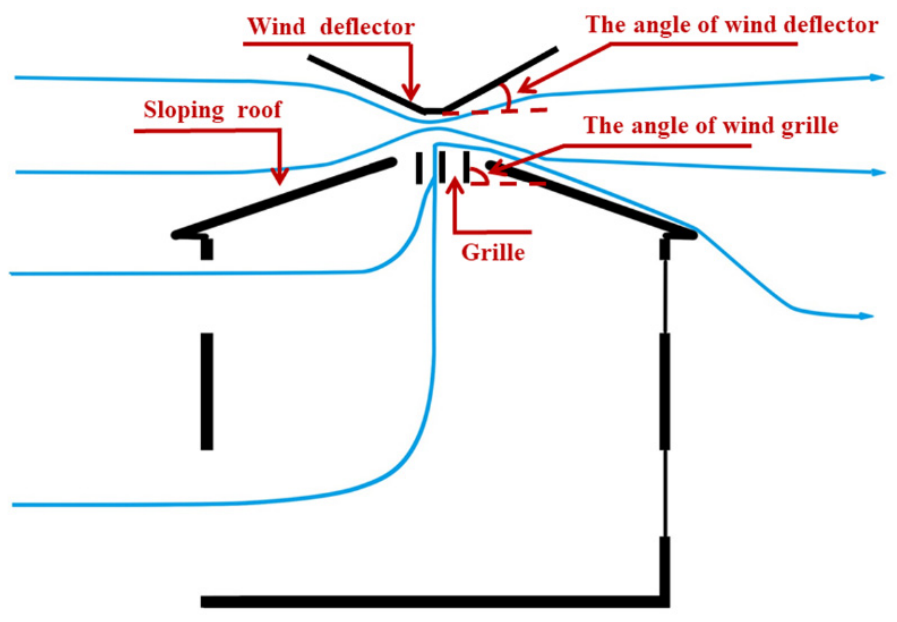

Figure 1. Schematic diagram of a venturi cap. 


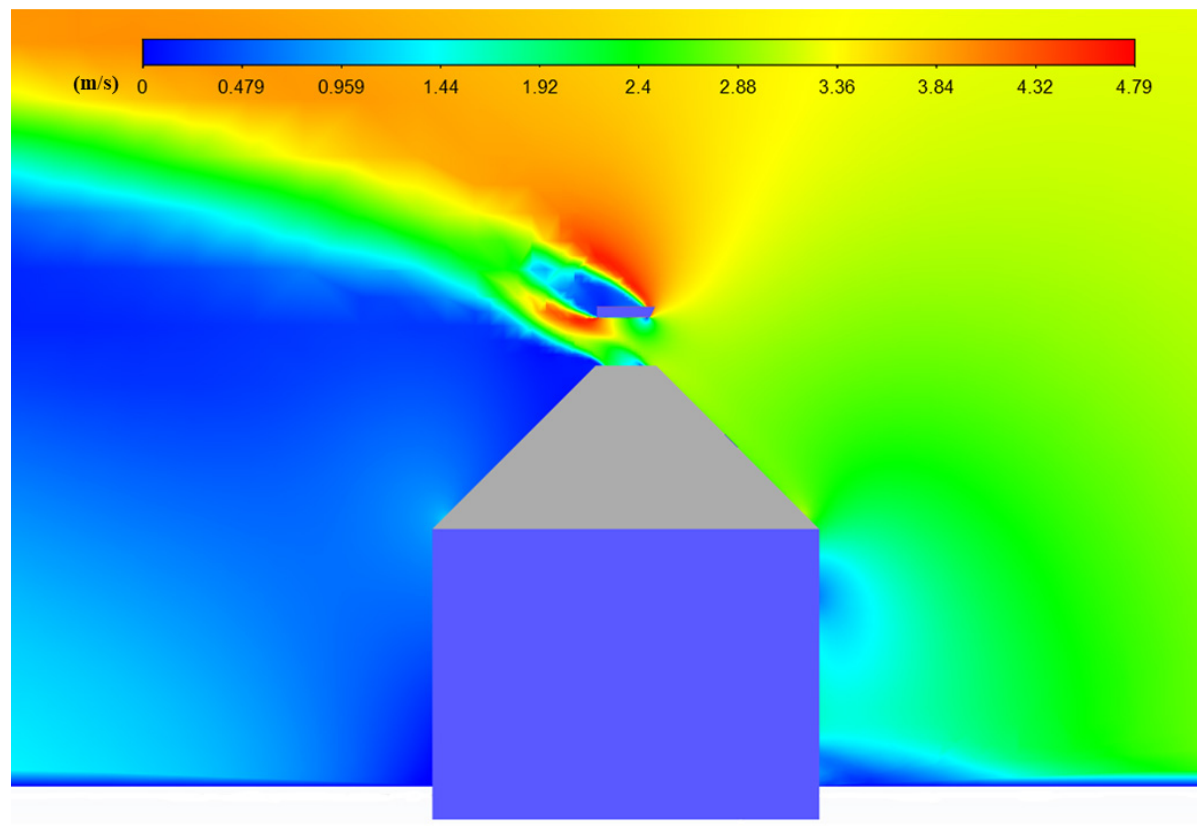

Figure 2. Acceleration due to the venturi effect, simulated by computational fluid dynamics (CFD).

\subsection{Research into Application of the Venturi Effect}

The most representative application of the venturi effect is the venturi tube (Figure 3), which has been widely using in various fields due to its simple structure and low cost [12] $\mathrm{Li}$ et al. [13] studied the influence of the geometrical parameters of the venturi tube on the cavitation phenomenon and microbubble generation. Shi et al. [14] conducted experimental and numerical studies on the cavitation phenomena in venturi tubes with different geometric shapes. Bimestre et al. [15], Zhu et al. [16], and Long et al. [17] explored the cavitation characteristics of venturi tubes. The application of the venturi effect goes far beyond this. Gonzalez-Perez et al. [18] enhanced the absorption of steam waste in the absence of a mechanical compressor by using the venturi effect. Perez et al. [19-21] studied the important role played by the venturi effect in the production of $\mathrm{O}_{2}$ from $\mathrm{H}_{2} \mathrm{O}_{2}$. Ji et al. [12], Xu et al. [22], and Yu et al. [23] showed that the venturi effect could be applied to the nozzle to improve its performance.
A: tube cross-sectional area
V: fluid velocity
P: hydrostatic pressure
$\rho:$ fluid density

h: absolute height difference of fluid column at part 1 and part 2

\section{$\Delta h$ : height difference between the wall of part 1 and part 2}

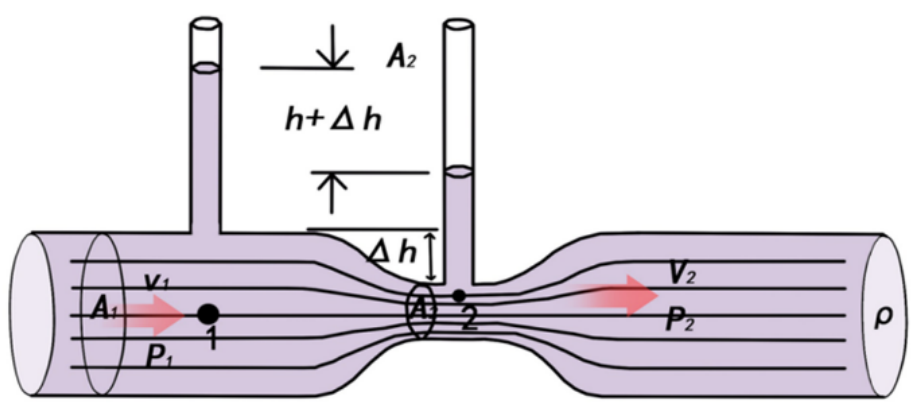

Figure 3. Schematic diagram of a venturi tube. 
The venturi effect also plays a positive role in agricultural production. Lei et al. [24] studied the movement of rapeseed and wheat seeds in the venturi seed feeding device and provided suggestions for improving the operating performance of seed feeding devices. Moreover, Quiroz-Perez et al. [25] used CFD simulation to find that the venturi device was able to generate a gas-liquid flow, thus increasing the gas production in some types of gas wells. Pan et al. [26] optimized the outlet of a smoke exhaust fan based on the venturi effect using an orthogonal design, a comprehensive scoring method, and the range analysis method, improving its smoke exhaust performance. Li [27] used the venturi effect to strengthen the natural smoke exhaust. On the basis of theoretical analysis, CFD numerical simulation, and wind tunnel experiments, a natural smoke exhaust device under the venturi effect was designed. Oliveira, M.A.d. et al. [28] studied the influence of the venturi effect on the control and suppression of vortex shedding in a slightly rough cylinder using the discrete vortex method. Shishodia et al. [29] applied the venturi effect in helmet design to improve the local airflow velocity in the gap between the head and the helmet, increasing the thermal comfort of riders.

With decreasing cross-section area, the flow velocity in building passages increases, as has been widely recognized and disseminated [30]. For integrated buildings with narrow gaps, building installations with divergent channels at intersecting angles can lead to the formation of the venturi effect [31]. However, Blocken et al. [32] put forward a different view, doubting the feasibility of the venturi effect in urban wind environments, and suggesting that the wind-blocking effect leads to increases in near-surface wind speed. Li et al. [33] and Allegrini et al. [34] provided support for the views proposed by Blocken et al. [32] on the basis of experiments. Chong. et al. [35] and Wang et al. [36] studied a hybrid solar-wind-rain eco-roof system for buildings. The system enhanced the wind speed before the interaction between the wind and the wind turbine located between the roof, strengthening the effect of the wind turbine through a rational use of the venturi effect. Ameer et al. [37], inspired by the venturi effect, designed a narrow roof that could increase the wind speed when the wind passed between two obstacles on the roof. Blocken et al. and Hooff et al. [38-40] studied the effect of venturi roofs on ventilation and analyzed the effect of the venturi and wind-blocking effects on venturi roofs. Then, they discussed the relationship between the width of the venturi roof and roof performance. Kumar et al. [41] studied the use of the venturi effect to intensify the air pressure in the vertical void to enhance the lateral ventilation on the leeward side of a double-load apartment building. Li et al. [42] studied the venturi effect on the effect of transverse entrains on pollutant diffusion in a street canyon. Some studies have been devoted to finding the best window opening to effectively regulate indoor airflow intensity by using the venturi effect [43-46]. Muhsin et al. [47] showed that the natural ventilation performance of multi-story residential units could be enhanced by implementing an appropriate void structure. Wang et al. [48] aimed to build a relationship between wind energy potential and the configuration of two vertical buildings by studying the wind accumulation phenomenon of the venturi effect in the building environment. In addition, the venturi effect was used in the design of the escape passage in order to adsorb the airflow and generate stable air movement in the room. This effect makes it possible to generate airflow in indoor areas such as basements [49]. Paepe et al. [50] optimized the ventilation of a cowshed by enhancing the venturi effect by creating an opening along the ridge and adding a wind deflector in the cowshed. Therefore, it can be seen that the venturi effect has extensive application prospects in regions with abundant sources of wind energy, and the development of wind energy in the built environment will be a crucial topic for sustainable cities in the future.

\subsection{Summary}

To date, scholars have proposed many strategies and measures for effectively applying the venturi effect in order to improve the convenience of our lifestyles and production on the basis of studies of applications of the venturi effect. However, by reviewing the research into applications of the effect, it can easily be found that that: 
Many scholars have performed numerous studies analyzing applications of the venturi effect applications; however, there is no comprehensive study evaluating the degree to which structural parameters affect the ventilation performance of the venturi effect.

Therefore, in line with the above summary, in this paper, the application of the venturi effect in building ventilation and the influence of various parameters on ventilation effect will be studied, and a venturi cap structure suitable for use in the Xichang area will be proposed.

\section{Methodology}

\subsection{Physical Model}

In the early days, the Yi people in Liangshan Prefecture lived together with poultry. Even now, this habit of habitation is still being preserved. Therefore, buildings have a high ventilation demand. The house structure, comprising raw soil and produced through wooden structure trusses, is a common building type for the middle class among the Yi in Liangshan [51]. The building is made of columns, beams, and wooden structure roof trusses as the frame of the house, and the components are connected. The wall is made of a wall compacted with raw soil, with wall thickness reaching up to $350 \mathrm{~mm}$ [52]. While investigating the residential forms in the town of Huanglianguan in Xichang, scholars found that buildings with a depth of $3500 \mathrm{~mm}-4200 \mathrm{~mm}$ and a face width of $5500 \mathrm{~mm}-6400 \mathrm{~mm}$ account for the largest proportion in the local area [53]. Therefore, as shown in Figure 4, this study selected buildings with sizes of $6 \mathrm{~m} \times 4 \mathrm{~m}$ for the study. The thickness of the building walls was $350 \mathrm{~mm}$, while the height of the cornice was $3000 \mathrm{~mm}$, and the roof was covered in wood with a thickness of $50 \mathrm{~mm}$ and grass much with a thickness of $30 \mathrm{~mm}$. As is shown in Table 1, the building height was related to the sloping roof and the width of the roof opening. The venturi cap was arranged along the ridge of roof. The thickness of the grille was $10 \mathrm{~mm}$. The width of the grille was equal to the width of the gap between the grilles, allowing the grille to close easily. There was also a door on the other wall of the room, which was $1200 \mathrm{~mm}$ wide and $2000 \mathrm{~mm}$ high, to provide airflow from the outside.

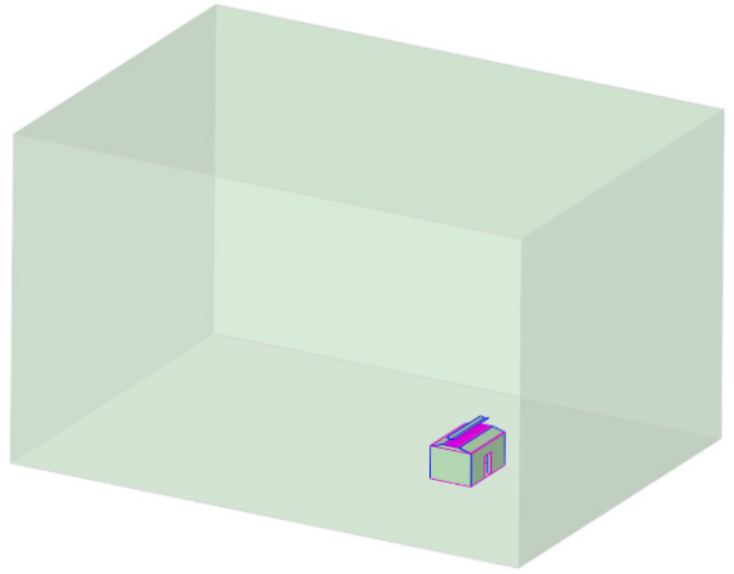

(a)

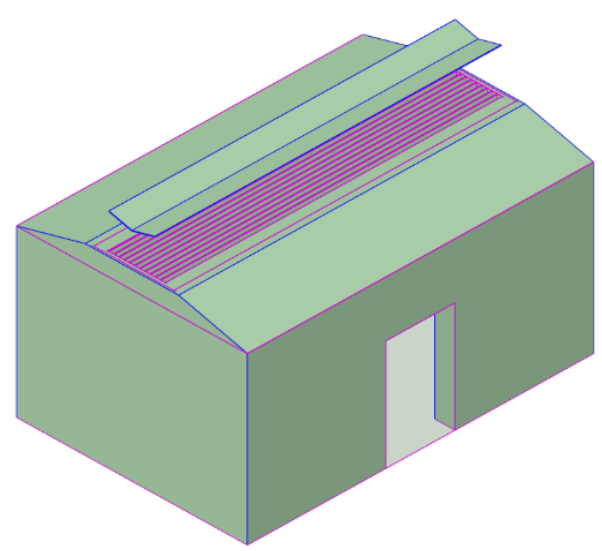

(b)

Figure 4. Numerical model constructed by computational fluid dynamics (CFD). (a) Complete model; (b) local model. 
Table 1. Orthogonal design arrangements and results.

\begin{tabular}{|c|c|c|c|c|c|c|c|c|c|}
\hline Scene & $\begin{array}{l}\text { Width of Roof } \\
\text { Opening }(\mathrm{mm})\end{array}$ & Roof Slope $\left({ }^{\circ}\right)$ & $\begin{array}{l}\text { Height of Wind } \\
\text { Deflector }(\mathrm{mm})\end{array}$ & $\begin{array}{c}\text { Horizontal } \\
\text { Width of Wind } \\
\text { Deflector }(\mathrm{mm})\end{array}$ & $\begin{array}{l}\text { Angle of Wind } \\
\text { Deflector }\left(^{\circ}\right)\end{array}$ & $\begin{array}{c}\text { Angle of Grille } \\
\left({ }^{\circ}\right)\end{array}$ & $\begin{array}{l}\text { Spacing of Grille } \\
\text { Slices (mm) }\end{array}$ & $\begin{array}{c}\text { Building } \\
\text { Height }(\mathrm{mm})\end{array}$ & $\begin{array}{c}\text { Volume Flow } \\
\text { Rate }\left(\mathrm{m}^{3} / \mathrm{s}\right)\end{array}$ \\
\hline N1 & $400\left(\mathrm{~A}_{1}\right)$ & $45\left(B_{3}\right)$ & $600\left(C_{3}\right)$ & $600\left(D_{3}\right)$ & $0\left(E_{1}\right)$ & $75\left(\mathrm{~F}_{3}\right)$ & $20\left(G_{1}\right)$ & 3843.430 & 3.399 \\
\hline $\mathrm{N} 2$ & $800\left(\mathrm{~A}_{3}\right)$ & $30\left(B_{2}\right)$ & $600\left(C_{3}\right)$ & $200\left(D_{1}\right)$ & $0\left(E_{1}\right)$ & $60\left(\mathrm{~F}_{2}\right)$ & $80\left(G_{4}\right)$ & 3415.690 & 4.563 \\
\hline N3 & $600\left(A_{2}\right)$ & $60\left(\mathrm{~B}_{4}\right)$ & $600\left(C_{3}\right)$ & $400\left(D_{2}\right)$ & $15\left(\mathrm{E}_{2}\right)$ & $45\left(\mathrm{~F}_{1}\right)$ & $20\left(G_{1}\right)$ & 4392.245 & 3.553 \\
\hline N4 & $600\left(\mathrm{~A}_{2}\right)$ & $15\left(\mathrm{~B}_{1}\right)$ & $400\left(C_{2}\right)$ & $400\left(\mathrm{D}_{2}\right)$ & $0\left(\mathrm{E}_{1}\right)$ & $60\left(\mathrm{~F}_{2}\right)$ & $40\left(G_{2}\right)$ & 3372.690 & 4.576 \\
\hline N5 & $600\left(\mathrm{~A}_{2}\right)$ & $45\left(\mathrm{~B}_{3}\right)$ & $800\left(C_{4}\right)$ & $600\left(D_{3}\right)$ & $30\left(E_{3}\right)$ & $45\left(\mathrm{~F}_{1}\right)$ & $80\left(G_{4}\right)$ & 3793.430 & 4.015 \\
\hline N6 & $800\left(\mathrm{~A}_{3}\right)$ & $15\left(\mathrm{~B}_{1}\right)$ & $800\left(C_{4}\right)$ & $800\left(D_{4}\right)$ & $45\left(\mathrm{E}_{4}\right)$ & $60\left(\mathrm{~F}_{2}\right)$ & $20\left(G_{1}\right)$ & 3345.900 & 4.297 \\
\hline N8 & $1000\left(\mathrm{~A}_{4}\right)$ & $15\left(\mathrm{~B}_{1}\right)$ & $600\left(C_{3}\right)$ & $800\left(\mathrm{D}_{4}\right)$ & $15\left(E_{2}\right)$ & $90\left(\mathrm{~F}_{4}\right)$ & $80\left(G_{4}\right)$ & 3319.100 & 4.553 \\
\hline N9 & $600\left(\mathrm{~A}_{2}\right)$ & $45\left(B_{3}\right)$ & $800\left(C_{4}\right)$ & $800\left(\mathrm{D}_{4}\right)$ & $0\left(E_{1}\right)$ & $90\left(\mathrm{~F}_{4}\right)$ & $40\left(G_{2}\right)$ & 3793.430 & 4.133 \\
\hline N10 & $1000\left(\mathrm{~A}_{4}\right)$ & $45\left(B_{3}\right)$ & $200\left(C_{1}\right)$ & $400\left(D_{2}\right)$ & $15\left(\mathrm{E}_{2}\right)$ & $60\left(\mathrm{~F}_{2}\right)$ & $80\left(G_{4}\right)$ & 3693.430 & 4.458 \\
\hline N11 & $1000\left(\mathrm{~A}_{4}\right)$ & $60\left(B_{4}\right)$ & $400\left(C_{2}\right)$ & $600\left(D_{3}\right)$ & $30\left(E_{3}\right)$ & $60\left(\mathrm{~F}_{2}\right)$ & $20\left(G_{1}\right)$ & 4219.040 & 4.829 \\
\hline N12 & $400\left(\mathrm{~A}_{1}\right)$ & $15\left(\mathrm{~B}_{1}\right)$ & $200\left(C_{1}\right)$ & $200\left(D_{1}\right)$ & $0\left(E_{1}\right)$ & $45\left(\mathrm{~F}_{1}\right)$ & $20\left(G_{1}\right)$ & 3399.490 & 2.890 \\
\hline N13 & $1000\left(\mathrm{~A}_{4}\right)$ & $30\left(\mathrm{~B}_{2}\right)$ & $800\left(C_{4}\right)$ & $400\left(D_{2}\right)$ & $0\left(E_{1}\right)$ & $45\left(\mathrm{~F}_{1}\right)$ & $60\left(\mathrm{G}_{3}\right)$ & 3386.825 & 4.651 \\
\hline N14 & $800\left(\mathrm{~A}_{3}\right)$ & $60\left(\mathrm{~B}_{4}\right)$ & $200\left(C_{1}\right)$ & $600\left(\mathrm{D}_{3}\right)$ & $0\left(E_{1}\right)$ & $90\left(\mathrm{~F}_{4}\right)$ & $80\left(G_{4}\right)$ & 4305.640 & 4.105 \\
\hline N15 & $400\left(\mathrm{~A}_{1}\right)$ & $15\left(B_{1}\right)$ & $200\left(C_{1}\right)$ & $400\left(D_{2}\right)$ & $30\left(E_{3}\right)$ & $90\left(\mathrm{~F}_{4}\right)$ & $60\left(G_{3}\right)$ & 3399.490 & 3.887 \\
\hline N16 & $1000\left(\mathrm{~A}_{4}\right)$ & $45\left(B_{3}\right)$ & $200\left(C_{1}\right)$ & $200\left(D_{1}\right)$ & $45\left(E_{4}\right)$ & $75\left(\mathrm{~F}_{3}\right)$ & $40\left(G_{2}\right)$ & 3693.430 & 5.002 \\
\hline N18 & $400\left(\mathrm{~A}_{1}\right)$ & $60\left(B_{4}\right)$ & $800\left(C_{4}\right)$ & $400\left(D_{2}\right)$ & $45\left(E_{4}\right)$ & $75\left(\mathrm{~F}_{3}\right)$ & $80\left(G_{4}\right)$ & 4478.845 & 4.502 \\
\hline N19 & $600\left(A_{2}\right)$ & $60\left(B_{4}\right)$ & $600\left(C_{3}\right)$ & $200\left(D_{1}\right)$ & $45\left(E_{4}\right)$ & $90\left(\mathrm{~F}_{4}\right)$ & $60\left(\mathrm{G}_{3}\right)$ & 4392.245 & 4.816 \\
\hline N20 & $1000\left(\mathrm{~A}_{4}\right)$ & $15\left(\mathrm{~B}_{1}\right)$ & $600\left(C_{3}\right)$ & $600\left(D_{3}\right)$ & $45\left(\mathrm{E}_{4}\right)$ & $45\left(\mathrm{~F}_{1}\right)$ & $40\left(G_{2}\right)$ & 3319.100 & 4.804 \\
\hline N21 & $400\left(\mathrm{~A}_{1}\right)$ & $30\left(B_{2}\right)$ & $400\left(C_{2}\right)$ & $600\left(D_{3}\right)$ & $15\left(E_{2}\right)$ & $90\left(\mathrm{~F}_{4}\right)$ & $40\left(G_{2}\right)$ & 3473.425 & 3.888 \\
\hline N22 & $600\left(A_{2}\right)$ & $30\left(B_{2}\right)$ & $200\left(C_{1}\right)$ & $800\left(D_{4}\right)$ & $15\left(\mathrm{E}_{2}\right)$ & $75\left(\mathrm{~F}_{3}\right)$ & $20\left(G_{1}\right)$ & 3444.560 & 4.103 \\
\hline N23 & $800\left(\mathrm{~A}_{3}\right)$ & $45\left(B_{3}\right)$ & $400\left(C_{2}\right)$ & $200\left(D_{1}\right)$ & $15\left(\mathrm{E}_{2}\right)$ & $45\left(\mathrm{~F}_{1}\right)$ & $60\left(G_{3}\right)$ & 3743.430 & 4.628 \\
\hline N24 & $1000\left(\mathrm{~A}_{4}\right)$ & $30\left(B_{2}\right)$ & $800\left(C_{4}\right)$ & $200\left(D_{1}\right)$ & $30\left(E_{3}\right)$ & $90\left(\mathrm{~F}_{4}\right)$ & $20\left(G_{1}\right)$ & 3386.825 & 4.695 \\
\hline N25 & $800\left(\mathrm{~A}_{3}\right)$ & $30\left(B_{2}\right)$ & $600\left(C_{3}\right)$ & $400\left(D_{2}\right)$ & $30\left(E_{3}\right)$ & $75\left(\mathrm{~F}_{3}\right)$ & $40\left(G_{2}\right)$ & 3415.690 & 4.619 \\
\hline N26 & $600\left(\mathrm{~A}_{2}\right)$ & $15\left(\mathrm{~B}_{1}\right)$ & $400\left(C_{2}\right)$ & $200\left(D_{1}\right)$ & $30\left(E_{3}\right)$ & $75\left(\mathrm{~F}_{3}\right)$ & $80\left(\mathrm{G}_{4}\right)$ & 3372.690 & 4.610 \\
\hline N27 & $800\left(\mathrm{~A}_{3}\right)$ & $15\left(B_{1}\right)$ & $800\left(C_{4}\right)$ & $600\left(D_{3}\right)$ & $15\left(\mathrm{E}_{2}\right)$ & $75\left(\mathrm{~F}_{3}\right)$ & $60\left(G_{3}\right)$ & 3345.900 & 4.573 \\
\hline N28 & $400\left(\mathrm{~A}_{1}\right)$ & $45\left(B_{3}\right)$ & $600\left(C_{3}\right)$ & $800\left(D_{4}\right)$ & $30\left(E_{3}\right)$ & $60\left(\mathrm{~F}_{2}\right)$ & $60\left(G_{3}\right)$ & 3843.430 & 3.233 \\
\hline N29 & $600\left(\mathrm{~A}_{2}\right)$ & $30\left(B_{2}\right)$ & $200\left(C_{1}\right)$ & $600\left(D_{3}\right)$ & $45\left(\mathrm{E}_{4}\right)$ & $60\left(\mathrm{~F}_{2}\right)$ & $60\left(\mathrm{G}_{3}\right)$ & 3444.560 & 3.701 \\
\hline N30 & $1000\left(\mathrm{~A}_{4}\right)$ & $60\left(B_{4}\right)$ & $400\left(C_{2}\right)$ & $800\left(\mathrm{D}_{4}\right)$ & $0\left(E_{1}\right)$ & $75\left(\mathrm{~F}_{3}\right)$ & $60\left(\mathrm{G}_{3}\right)$ & 4219.040 & 4.431 \\
\hline N31 & $800\left(\mathrm{~A}_{3}\right)$ & $45\left(B_{3}\right)$ & $400\left(C_{2}\right)$ & $400\left(D_{2}\right)$ & $45\left(\mathrm{E}_{4}\right)$ & $90\left(\mathrm{~F}_{4}\right)$ & $20\left(G_{1}\right)$ & 3743.430 & 4.369 \\
\hline N32 & $400\left(\mathrm{~A}_{1}\right)$ & $30\left(B_{2}\right)$ & $400\left(C_{2}\right)$ & $800\left(\mathrm{D}_{4}\right)$ & $45\left(E_{4}\right)$ & $45\left(\mathrm{~F}_{1}\right)$ & $80\left(G_{4}\right)$ & 3473.425 & 2.370 \\
\hline
\end{tabular}




\subsection{Numerical Scheme}

The orthogonal experimental design is a method used to study multiple factors at multiple levels. It is an efficient, rapid, and economical experimental design method that selects representative points from comprehensive tests according to the principle of orthogonality. This paper studies the effects of seven factors: (A) width of roof opening; (B) roof slope; (C) height of wind deflector; (D) horizontal width of wind deflector; (E) angle of wind deflector; (F) angle of grille; (G) spacing of grille slices. As shown in Table 1, each factor has four different levels. Because the full factor design required $4^{7}=16,384$ experiments, the orthogonal experimental design was adopted to reduce the number of experiments and improve the experimental efficiency. Table 1 shows the results of the orthogonal experimental design using an IBM SPSS 25.0, which produced 32 simulation scenarios. To better show the changes in these parameters, the model was decomposed according to its structure. Figure 5 shows the changes in the roof, grille, and wind deflector.
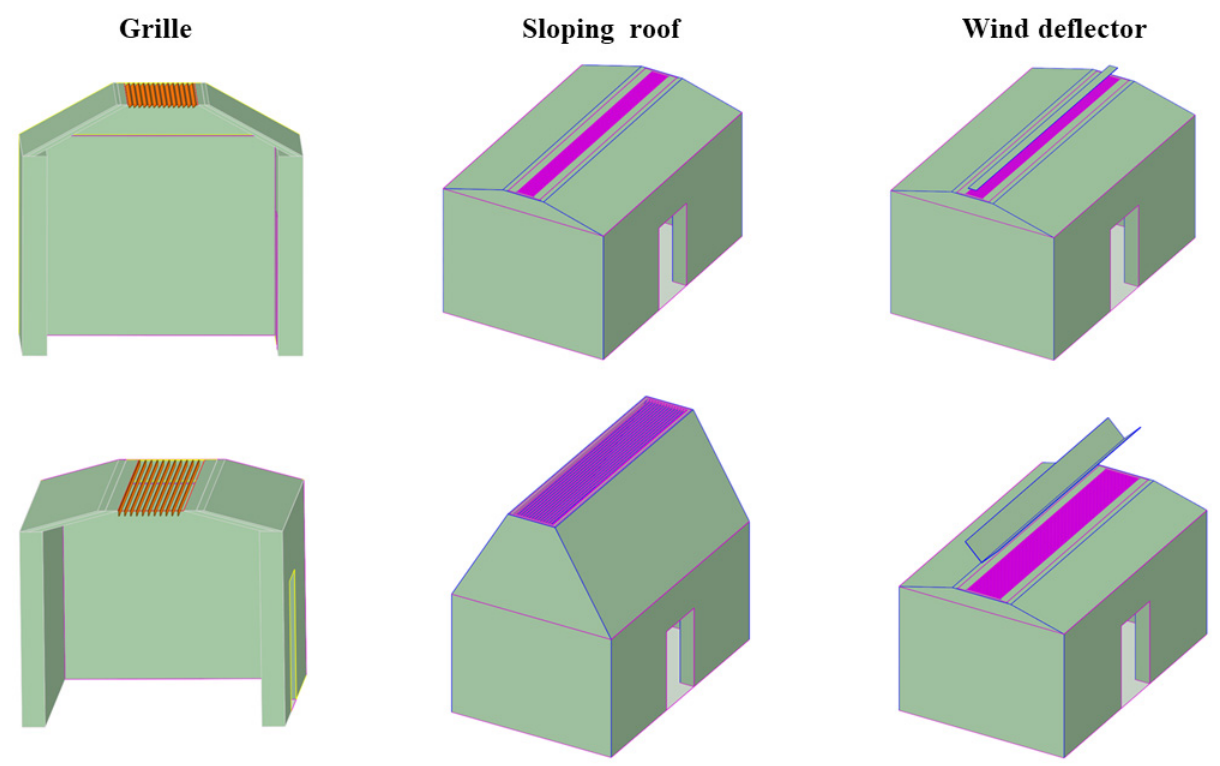

Figure 5. Changes in various structures.

\subsection{Numerical Simulation}

\subsubsection{Physical Properties of Building Materials and Boundary Conditions}

Table 2 summarizes the physical properties of the building materials, and these materials were used to simulate the heat conduction in the structure. The grille of the venturi cap is made of wood, while the wind deflector is made from aluminum alloy, the indoor floor is concrete, the outdoor floor is earth, and the wall is rammed earth. All of the necessary thermophysical properties of the building materials and air are assumed to be constant, except for the air density, which is considered to be an ideal gas. The size of the air domain outside the model is $50 \mathrm{~m} \times 36 \mathrm{~m} \times 30 \mathrm{~m}$. The inlet boundary condition of the model is velocity-inlet. The outlet is a pressure outlet, and the remaining surfaces are set to be symmetrical. The door and grille are set to the interior. The optimization of natural indoor ventilation in Xichang in summer is the main aspect under consideration. Therefore, the model adopts the predominant wind direction in Xichang during summer, and the predominant wind direction in Xichang is north-south [11]. The meteorological data used for the weather energy of Xichang in the numerical simulation were obtained from Chinese Standard Weather Data (CSWD) files, which were downloaded from the website [54] and are suitable for China [55]. In the numerical simulation, the meteorological data for summer days in the Xichang area were selected, and therefore the outside temperature was set at $300 \mathrm{~K}$ and the wind speed was $3.3 \mathrm{~m} / \mathrm{s}$. 
Table 2. Material properties of the venturi cap.

\begin{tabular}{cccc}
\hline Material Properties & Density $\mathbf{( k g / \mathbf { m } ^ { 3 } )}$ & Conductivity $(\mathbf{W} /(\mathbf{m} \times \mathbf{k}))$ & Specific Heat $(\mathbf{J} /(\mathbf{k g} \times \mathbf{k}))$ \\
\hline Adobe & 1800 & 0.93 & 1010 \\
Wood & 500 & 0.14 & 2510 \\
Al & 2719 & 202.4 & 871 \\
Concrete & 2300 & 1.51 & 920 \\
\hline
\end{tabular}

\subsubsection{Grid Division}

To ensure the independence of the mesh, four grid sizes were used for the experiments: 1,347,614 (1\#), 1,919,598 (2\#), 2,269,404 (3\#) and 2,651,469 (4\#). Figure 6 shows the experimental convergence results under four different meshing conditions. The difference in the volume flow rate between $1 \#$ and $2 \#$ was $40.833 \%$, that between $2 \#$ and $3 \#$ was $1.650 \%$, and that between $2 \#$ and $4 \#$ was $0.259 \%$. Finally, the partition method of 1,919,598 (2\#) was selected. In addition, as shown in Figure 7, the poly-hex core grid type was adopted to mesh the model. The global minimum surface mesh was $48.828 \mathrm{~mm}$, and the global maximum surface mesh was $1000 \mathrm{~mm}$. The local surface mesh of the door, indoor floor, wall, and roof was set as $80 \mathrm{~mm}$, and the local surface mesh of the grilles and wind deflector was set as $20 \mathrm{~mm}$. The minimum mesh volume was $20 \mathrm{~mm}$, the maximum mesh volume was $640 \mathrm{~mm}$, and three layers of the boundary were set to achieve a reasonable transition of the mesh.

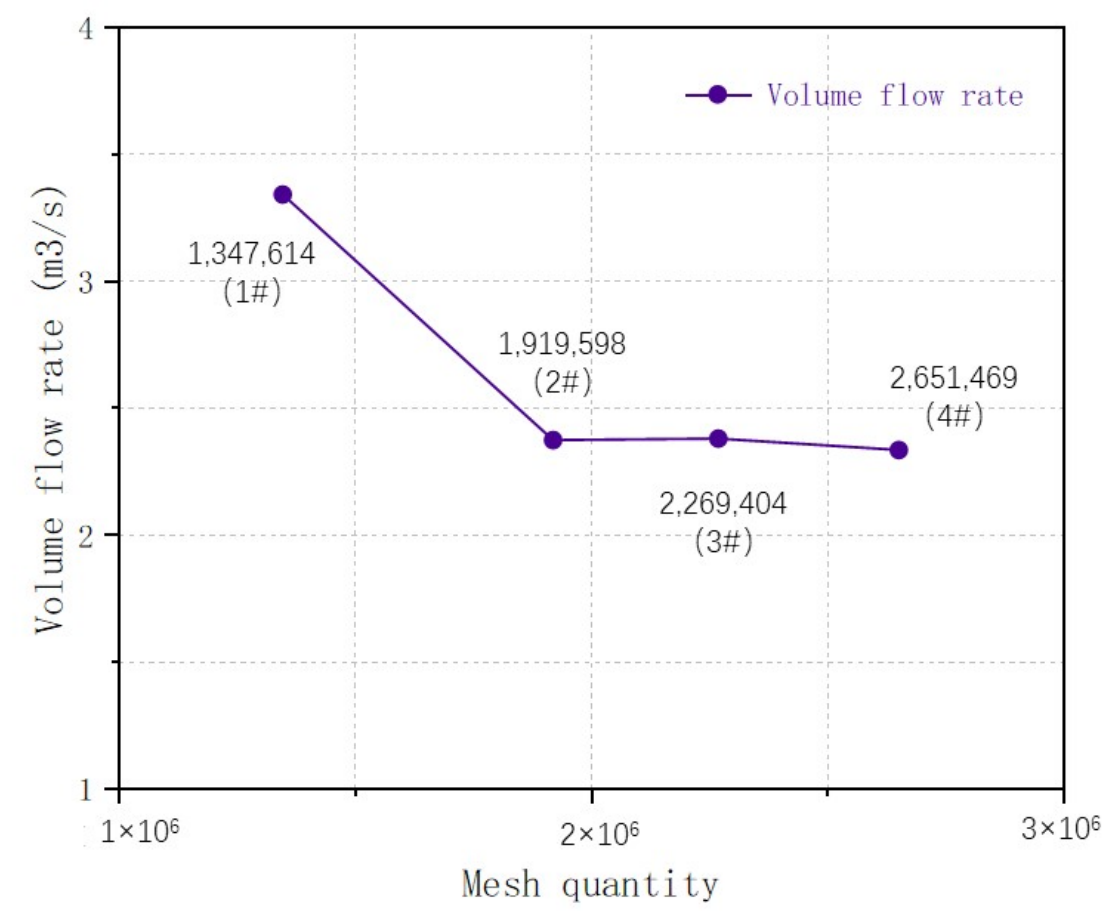

Figure 6. Volumetric flow rate under various grid sizes. 


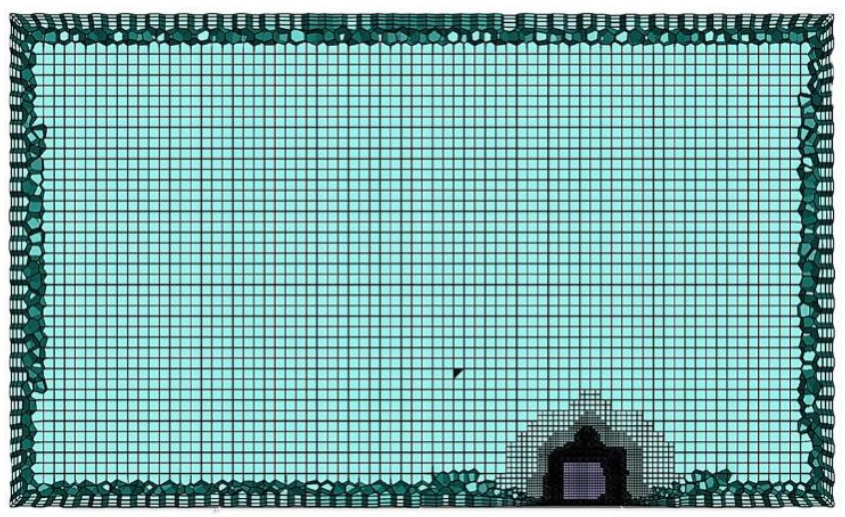

(a)

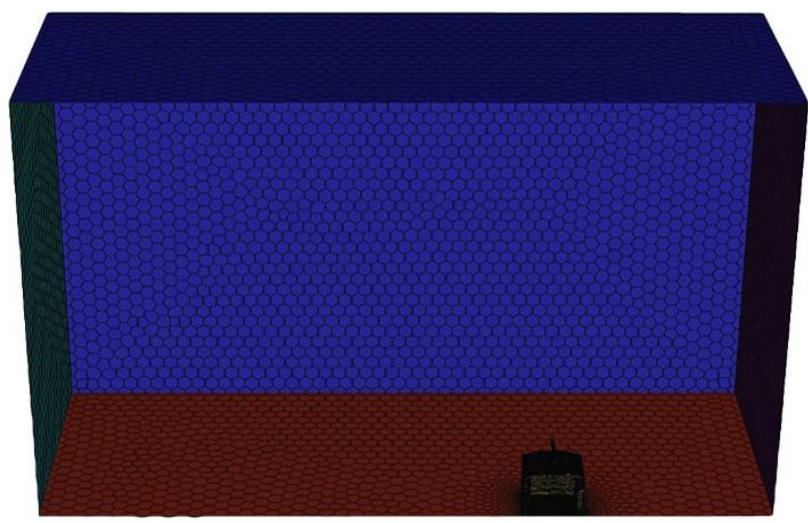

(b)

Figure 7. Computational fluid dynamics (CFD) meshing (2\#). (a) Volume mesh; (b) surface mesh.

\subsubsection{Computational Fluid Dynamics (CFD) Theory}

Numerical simulation was performed using ANSYS Fluent 2020 R2 using a finitevolume hydrodynamics solver. The simulation follows the laws of conservation of mass, momentum, and energy.

The mass conservation equation of the continuity equation is expressed as follows:

$$
\frac{\partial \rho}{\partial t}+\Delta(\rho \vec{V})=0
$$

where $\rho$ is the fluid density, $\overrightarrow{\mathrm{V}}$ is the velocity vector, and $\Delta(\rho \overrightarrow{\mathrm{V}})$ is the velocity divergence.

The momentum equation of viscous fluid is a mathematical expression of the law of conservation of momentum, which is expressed as follows:

$$
\frac{\partial}{\partial t}\left(\rho \vec{v}_{i}\right)+\Delta\left(\rho \vec{v} \vec{v}_{i}\right)=\Delta P_{i}+g_{i}-f_{i}
$$

where $\vec{v}_{i}$ is the velocity component in the direction of $i$; $P_{i}$ is the surface force vector, including static pressure and fluid viscous stress. $\mathrm{g}_{\mathrm{i}}$ is the volume force acting on the direction of unit volume flow $i$; $f_{i}$ is the resistance acting in the direction of unit volume flow.

The energy conservation equation is expressed as follows:

$$
\frac{\partial}{\partial t}(\rho \mathrm{E})+\Delta \overrightarrow{\mathrm{v}}(\rho \mathrm{E}+\mathrm{p})=\Delta \mathrm{k}_{\text {eff }} \Delta \mathrm{T}-\Sigma \mathrm{h}_{\mathrm{i}} \vec{j}_{\mathrm{i}}+(\tau \text { eff } \times \overrightarrow{\mathrm{v}})+\mathrm{S}_{\mathrm{h}}
$$

where $k_{\text {eff }}$ is the effective thermal conductivity $\left(k+k_{f}\right)$ with $k_{f}$ being the thermal conductivity caused by turbulence, and $\vec{j}_{i}$ is the diffusion flux of component $i$. The first term on the right-hand side of the equation represents the energy transfer due to heat conduction. The second term represents component diffusion, and the third term represents viscous dissipation. $\mathrm{S}_{\mathrm{h}}$ contains the heat of the chemical reaction and any other definable volume heat source.

In Fluent, the solar radiation model was adopted, and solar ray tracing was activated. Then, parameters such as latitude and longitude were set so that the computer could automatically calculate solar radiation intensity. The wall thermal boundary was Heat Flux, and the calculation formula for this was as follows:

$$
\mathrm{Tw}=\frac{\left(\mathrm{q}-\mathrm{q}_{\mathrm{rad}}\right) \Delta \mathrm{n}}{\mathrm{k}_{\mathrm{S}}}+\mathrm{Ts}
$$


where $k_{S}$ is the heat conduction coefficient of a solid; $\Delta \mathrm{n}$ is the distance from the wall surface to the center of the unit of the first layer; Ts is the temperature of the solid wall surface; $\mathrm{q}$ is the input heat flux; and $\mathrm{q}_{\mathrm{rad}}$ is the radiant heat flux.

In the numerical simulation, the realizable $\mathrm{K}-\varepsilon$ turbulence model was selected. The $\mathrm{K}-\varepsilon$ turbulence model is the most commonly used two-equation turbulence model [56]. The realizable $\mathrm{K}-\varepsilon$ turbulence model is appropriate for complex shear flows involving rapid strain, slight rotation, vortex, and local transition flow. Therefore, the model is suitable for the study of indoor environments.

\section{Results and Discussion}

\subsection{Analysis of Variance}

Thirty-two scenarios were numerically simulated, and the volume flow of the venturi cap device is shown in Table 1. Range analysis and analysis of variance (ANOVA) are commonly used to analyze the experimental results of orthogonal design [56]. ANOVA was chosen for this study, and the variance analysis table of the volume flow rate is given (see Table 3). Based on the ANOVA performed on the results of the numerical simulation, we obtained the optimal level for each factor. In addition, on the basis of the $p$-value, the influencing factors were ranked. If a factor has a $p$-value less than or equal to 0.01 , then there is $99 \%$ or so probability that the factor has a highly significant impact on overall performance. If the $p$-value is between 0.01 and 0.05 , the probability drops, and the factor can be regarded as having a significant impact on overall performance. If the $p$-value is greater than 0.05 , the effect of this factor is not significant.

Table 3. Analysis of variance (ANOVA) table for volume flow rate.

\begin{tabular}{ccc}
\hline Factor & $p$ & Significance \\
\hline Width of roof opening & 0.001 & Highly significant \\
Roof slope & 0.737 & Not significant \\
Height of wind deflector & 0.224 & Not significant \\
Horizontal width of wind deflector & 0.043 & Significant \\
Angle of wind deflector & 0.86 & Significant \\
Angle of grille & 0.037 & Not significant \\
Spacing of the grille slices & 0.444 & \\
\hline
\end{tabular}

On the basis of the analysis of the simulation results of the venturi cap with different structural parameters, it can be observed that the width of the roof opening has a highly significant impact on the volume flow rate, followed by the angle of the grille, the horizontal width of the wind deflector, the wind deflector height, the spacing of the grille slices, the roof slope, and the angle of the wind deflector (see Tables 1 and 3). The specific order of influence is as follows: width of roof opening $>$ angle of grille $>$ horizontal width of wind deflector $>$ height of wind deflector $>$ spacing of grille slices $>$ roof slope $>$ angle of wind deflector.

In the analysis of the orthogonal experiment results, the level of each factor can be regarded as good if it corresponds to a larger volume of flow rate. When the width of the roof opening, angle of the grille, horizontal width of wind deflector, height of wind deflector, spacing of grille slices, roof slope, and angle of wind deflector were assigned values of $1000 \mathrm{~mm}\left(\mathrm{~A}_{4}\right), 15^{\circ}\left(\mathrm{B}_{1}\right), 800 \mathrm{~mm}\left(\mathrm{C}_{4}\right), 200 \mathrm{~mm}\left(\mathrm{D}_{1}\right), 45^{\circ}\left(\mathrm{E}_{4}\right), 75^{\circ}\left(\mathrm{F}_{3}\right)$, and $40 \mathrm{~mm}$ $\left(G_{2}\right)$, respectively, this scenario was named N33 and the volume flow rate of the venturi cap was $5.220 \mathrm{~m}^{3} / \mathrm{s}$. As seen in Figure 8, N33 provided the maximum volume flow rate for the indoor environment and was therefore regarded as the optimum choice among these 33 scenarios. The velocity cloud diagram is shown in Figure 9. At the same time, in the same scenario, without the venturi cap, the average temperature of the horizontal plane at a height of $1.2 \mathrm{~m}$ above the ground was $308.836 \mathrm{~K}$, while when the venturi cap was turned on, the average temperature of the plane was $305.997 \mathrm{~K}$, representing a reduction 
by $2.839 \mathrm{~K}$. These results show that the venturi cap plays a definite role in improving the ventilation conditions.

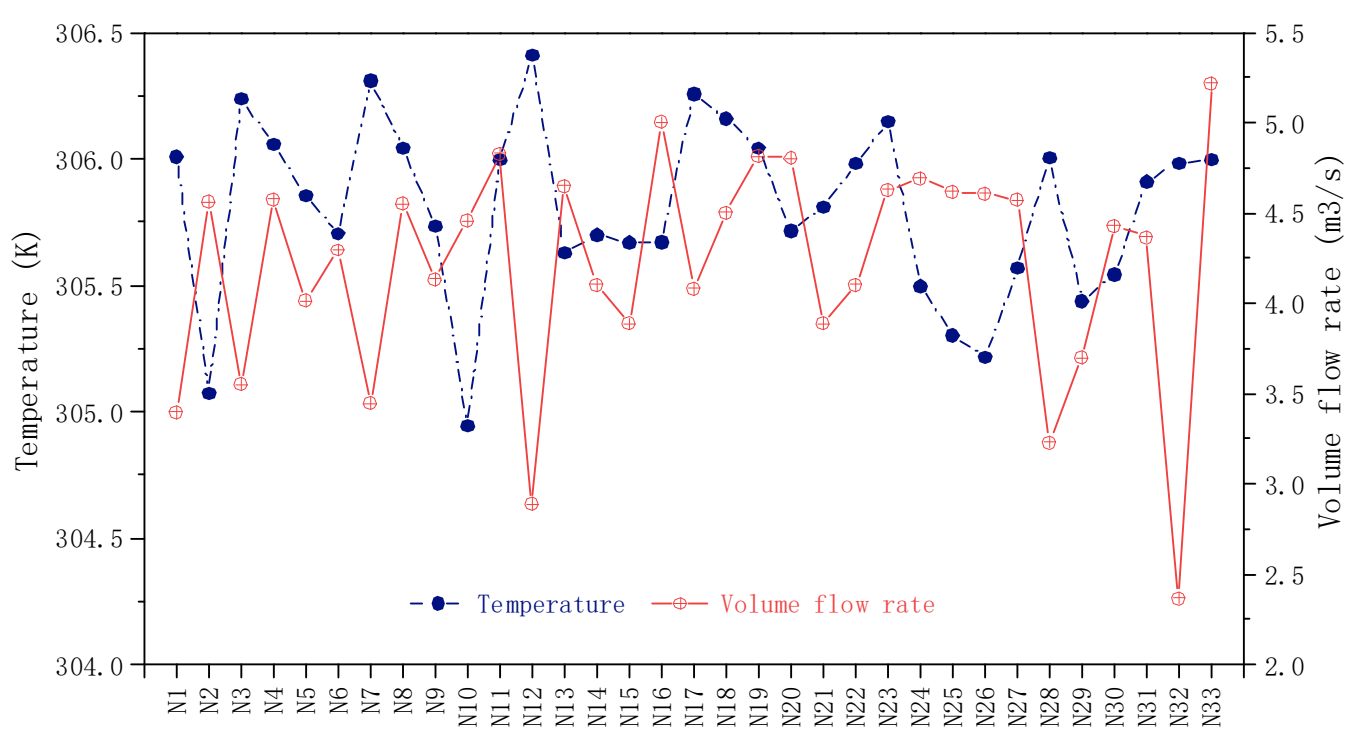

Figure 8. Volumetric flow and average temperature of a horizontal plane at a height of $1.2 \mathrm{~m}$ above the ground in 33 scenarios.

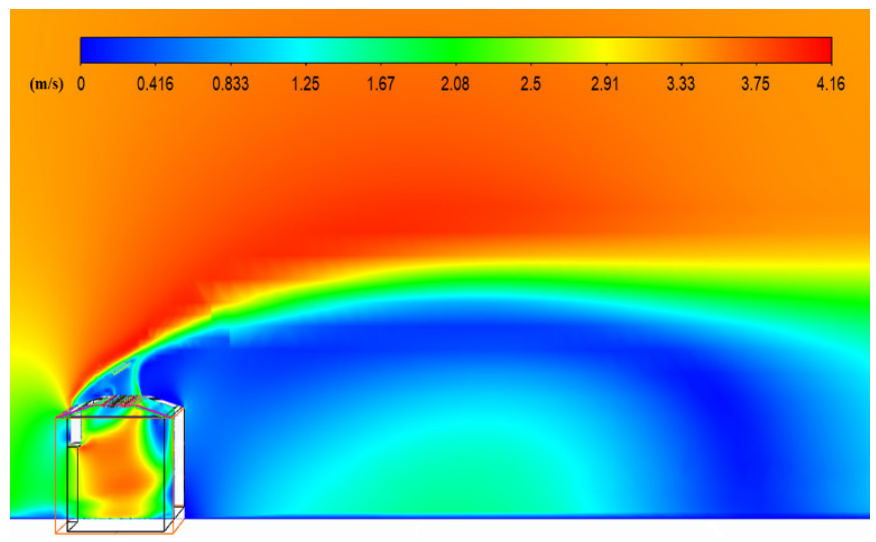

(a)

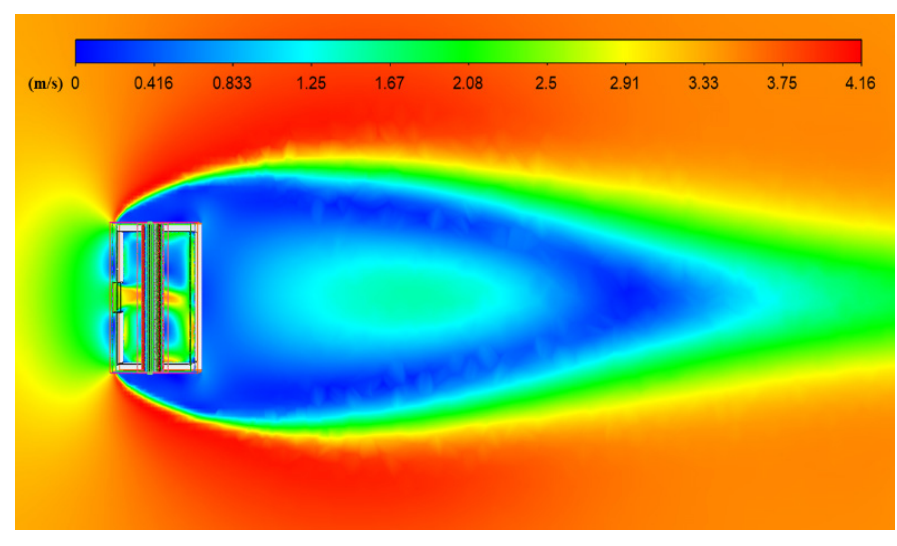

(b)

Figure 9. Velocity cloud diagram of the N33 scenario. (a) Side view; (b) plan view.

\subsection{Single Factor Study}

On the basis of the results of the variance analysis, it can be seen that the only highly significant factor affecting the effect of the venturi cap is the width of the roof opening. The angle of the grille and the width of the wind deflector have significant effects, while the other factors have insignificant effects. To determine the optimal design, the highly significant factor and the significant factors were studied in these 33 scenarios.

In N33, a single factor study was carried out on the highly significant factor. Only the width of the roof opening was changed, and the other six factors were fixed. The volumetric flow rate of the venturi cap and the average temperature of the $1.2 \mathrm{~m}$ horizontal plane were obtained through numerical simulation, as shown in Figure 10. When the width of the roof opening was changed in the range between $0 \mathrm{~mm}$ and $2000 \mathrm{~mm}$, the volume flow rate of the venturi cap was the best at $1000 \mathrm{~mm}$, with a maximum flow volume of $5.220 \mathrm{~m}^{3} / \mathrm{s}$. This indicates that $\mathrm{N} 33\left(\mathrm{~A}_{4} \mathrm{~B}_{1} \mathrm{C}_{4} \mathrm{D}_{1} \mathrm{E}_{4} \mathrm{~F}_{3} \mathrm{G}_{2}\right)$ is still the optimal combination when the width of the roof opening is within the range of $0 \mathrm{~mm}-2000 \mathrm{~mm}$. 


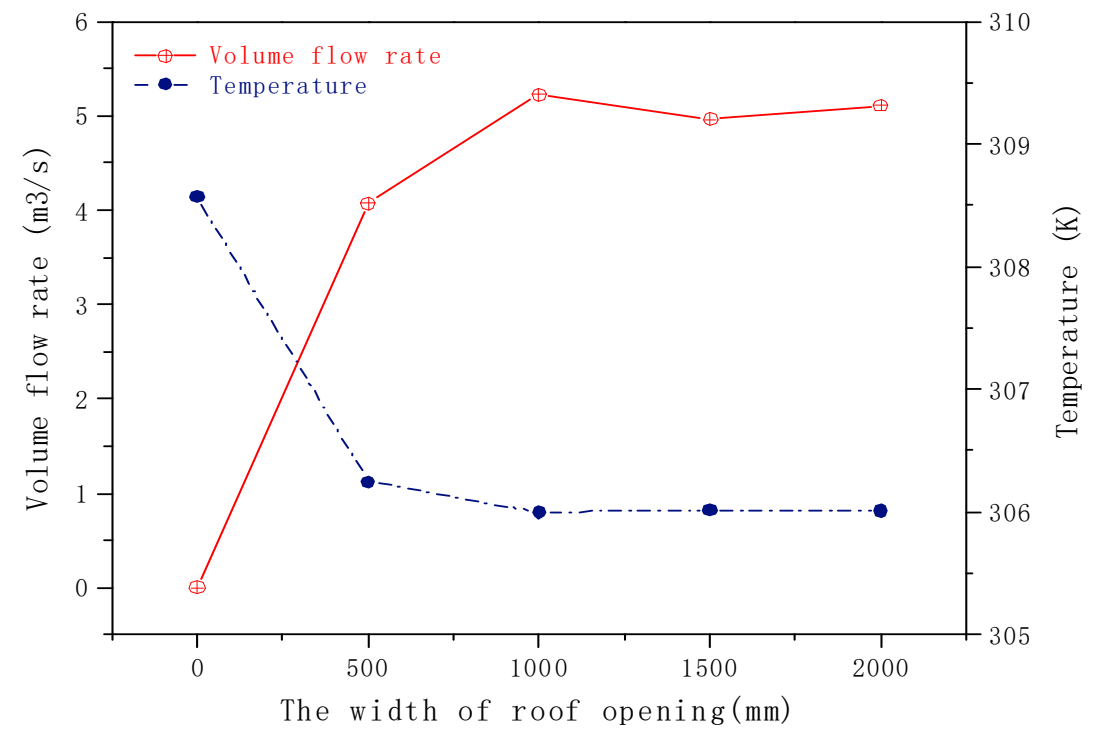

Figure 10. Volumetric flow and temperature values for different widths of roof opening.

Single factor studies were carried out for the significant factors. Only the horizontal width of the wind deflector was changed, and the other six factors were fixed. The volume flow rate of the venturi cap and the average temperature of $1.2 \mathrm{~m}$ high horizontal plane above the ground were obtained on the basis of numerical simulation, as shown in Figure 11. When the horizontal width of the wind deflector was changed in the range of $200 \mathrm{~mm}-1000 \mathrm{~mm}$, the volume flow rate of the venturi cap had the best value at $400 \mathrm{~mm}$, where the volume flow rate reached a maximum of $5.507 \mathrm{~m}^{3} / \mathrm{s}$. This shows that when the horizontal width of the wind deflector was within the range of $200 \mathrm{~mm}-1000 \mathrm{~mm}$, the volume flow rate first increased and then decreased with increasing horizontal width of the wind deflector. Similar to the analysis of the horizontal width of the wind deflector, the angle of the grille was studied. The results are presented in Figure 12. When the grille angle was $75^{\circ}$, the volume flow rate reached its maximum value.

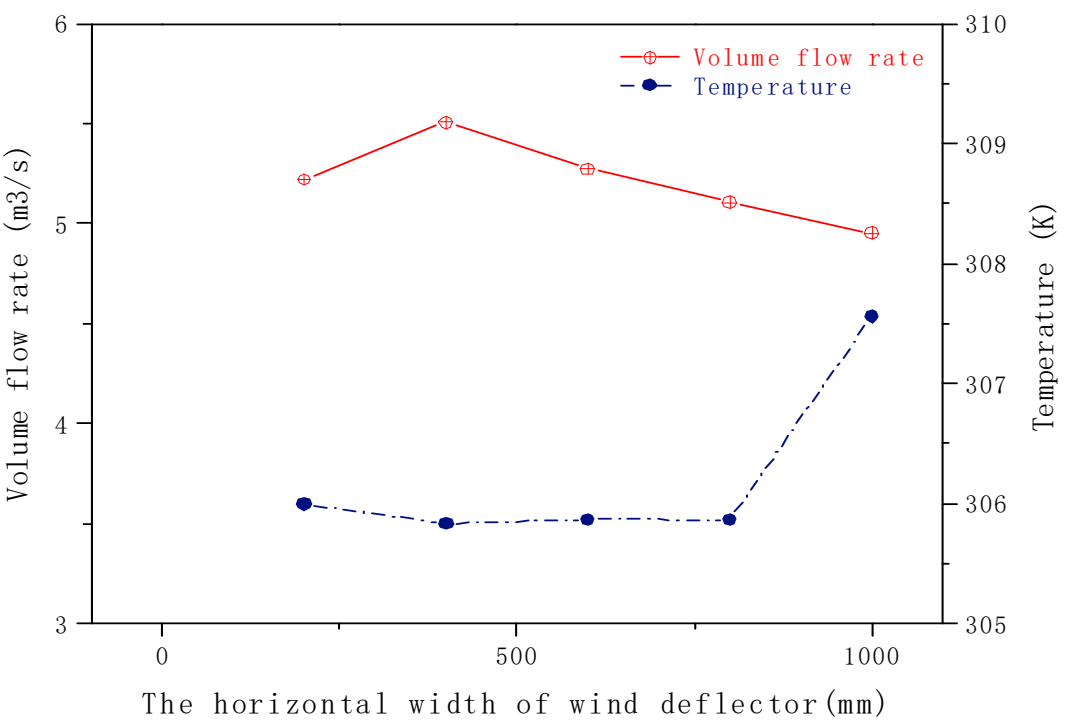

Figure 11. Values of volumetric flow and temperature at different horizontal widths of the wind deflector. 


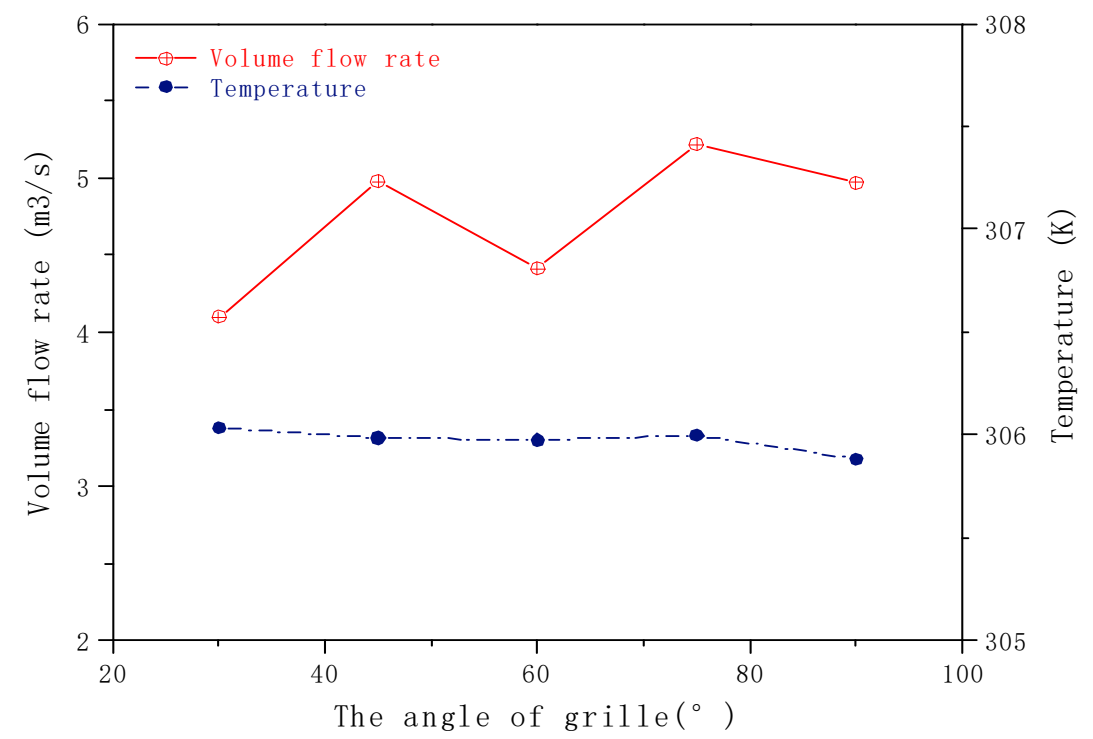

Figure 12. Volumetric flow and temperature values at different angles of grille.

On the basis of the analysis of the above parameters, N34 $\left(\mathrm{A}_{4} \mathrm{~B}_{1} \mathrm{C}_{4} \mathrm{D}_{2} \mathrm{E}_{4} \mathrm{~F}_{3} \mathrm{G}_{2}\right)$ was obtained by adjusting the horizontal width of the wind deflector to $400 \mathrm{~mm}$ on the basis of $\mathrm{N} 33$, and the maximum volume flow rate achieved was $5.507 \mathrm{~m}^{3} / \mathrm{s}$. At the same time, in the same scenario, without the venturi cap, the average temperature of the horizontal plane at a height of $1.2 \mathrm{~m}$ above the ground in the whole building was $308.836 \mathrm{~K}$, while when the venturi cap was turned on, the average temperature of the plane was $305.834 \mathrm{~K}$, which is a reduction by $3.002 \mathrm{~K}$. Therefore, it can be seen that the venturi cap is able to improve the ventilation of indoor environments and reduce indoor temperatures. In summer, this could lead to a reduction in the use of air conditioning equipment, thus achieving an energy-saving effect.

\section{Conclusions and Outlook}

\subsection{Conclusions}

The orthogonal experimental design and variance analysis were performed using SPSS, and the numerical simulation analysis was carried out using CFD. The feasibility of using a venturi cap in the Xichang area was verified. The main key factors influencing the venturi cap with respect to improving ventilation, and the degree of the effect were obtained. An optimized combination scheme was provided within the research scope and verified on the basis of numerical simulation. Therefore, the following conclusions can be drawn:

1. Variance analysis showed that the width of the roof opening had a highly significant effect on the ventilation performance of the venturi cap, while the angle of the grille and the horizontal width of the wind deflector had a significant impact. The height of the wind deflector, the spacing of the grille slices, roof slope, and the angle of the wind deflector were not significant.

2. On the basis of the analysis of the highly significant factors and the significant factors, it was found that the best solution was N34, that is, the width of the roof opening, the angle of the grille, the horizontal width of wind deflector, the height of wind deflector, the spacing of the grille slices, the roof slope and the angle of wind deflector were assigned values of $1000 \mathrm{~mm}\left(\mathrm{~A}_{4}\right), 15^{\circ}\left(\mathrm{B}_{1}\right), 800 \mathrm{~mm}\left(\mathrm{C}_{4}\right), 400 \mathrm{~mm}\left(\mathrm{D}_{2}\right), 45^{\circ}\left(\mathrm{E}_{4}\right), 75^{\circ}$ $\left(\mathrm{F}_{3}\right)$, and $40 \mathrm{~mm}\left(\mathrm{G}_{2}\right)$, respectively; the volume flow rate reached $5.507 \mathrm{~m}^{3} / \mathrm{s}$, and the average temperature of the horizontal plane at a height of $1.2 \mathrm{~m}$ above the ground dropped by $3.002 \mathrm{~K}$.

This research on building ventilation in the Xichang area showed that the structure is able to meet the needs of both residents and building characteristics, optimizing the 
ventilation conditions of local buildings while reducing indoor temperature and improving indoor air quality.

\subsection{Outlook}

In this study, the length-width ratio and shape of the venturi cap were not taken into consideration. The length of the venturi cap was set at a fixed length, and the area was converted into the width for the purposes of research. The thickness of the grille was also directly set at a fixed thickness, ignoring the possible influence of the change in the thickness of the grille on the ventilation conditions. The size and location of the air inlet were also fixed. In future research, these influencing factors should be further analyzed in order to put forward suggestions for the better application of the venturi effect in buildings and to provide design ideas and data references for the optimal design of building ventilation.

China's building energy consumption report 2020 reported that in 2018, China's total energy consumption was 2.147 billion tons of standard coal equivalent (tce), and its total carbon emissions were 4.93 billion $\mathrm{t} \mathrm{CO}_{2}$. Rural residential buildings account for $24 \%$ of China's building energy consumption and $21 \%$ of its carbon emissions, which are huge numbers. The application of a venturi cap in architectural design can increase indoor ventilation, bring more fresh outdoor air into the room, and reduce indoor temperature. The reduction in the use of air-conditioning systems during the summer will help to achieve the aim of reducing building energy consumption. Research regarding the venturi cap could provide design ideas for the future reconstruction of old rural buildings in the Xichang area in the future. In addition, in the context of COVID-19, indoor ventilation has become more important. Fresh air is able to dilute any harmful substances in the air and reduce the concentration of $\mathrm{CO}_{2}$, which is important for human health.

Author Contributions: Conceptualization, L.Z.; Data curation, L.T.; Funding acquisition, Q.S. and J.W.; Investigation, Z.D., H.L. (Haoru Liu) and J.W.; Methodology, L.Z., L.T., Q.S., F.L. and J.C.; Project administration, Q.S.; Software, L.T., H.L. (Haolin Li) and J.C.; Supervision, L.Z. and Q.S.; Visualization, L.T. and H.L. (Haolin Li); Writing-review \& editing, L.Z., L.T., F.L., Z.D. and H.L. (Haoru Liu). All authors have read and agreed to the published version of the manuscript.

Funding: This research was funded by Sichuan Provincial Research Center for Philosophy and Social Sciences-Sichuan Rural Development Research Center, grant number CR1908; the Chengdu Science and Technology Bureau Soft Science Project, grant number 2019-RK00-00319-ZF; and the Soft Science Project of Sichuan Provincial Science and Technology Department, grant number 2021JDR0076.

Institutional Review Board Statement: Not applicable.

Informed Consent Statement: Not applicable.

Data Availability Statement: The weather energy meteorological data of Xichang used in the numerical simulation are all from CSWD files, which are downloaded from the website: https:/ / energyplus. net/weather-location/asia_wmo_region_2/CHN//CHN_Sichuan.Xichang.565710_CSWD (accessed on 10 August 2020).

Acknowledgments: We would like to thank Yukai Qin, Jiarui Yu for their help to investigate and collect the data.

Conflicts of Interest: The authors declare no conflict of interest.

\section{References}

1. Bojić, M.; Johannes, K.; Kuznik, F. Optimizing energy and environmental performance of passive Trombe wall. Energy Build. 2014, 70, 279-286. [CrossRef]

2. Kwan, Y.; Guan, L. Design a Zero Energy House in Brisbane, Australia. Procedia Eng. 2015, 121, 604-611. [CrossRef]

3. Guo, J.; Guan, N.; Liu, H. Numerical Simulation of Natural Ventilation in a Zero-Energy Building-Optimal design of zero-energy solar housing prototype based on numerical simulation. Build. Energy Conserv. 2014, 42, 13-17.

4. Teng, J.; Li, M.; Wang, W.; Mu, X. A Study on Energy-saving Rate of Ventilation and Shading Technical Plans of Residential Buildings in Severely Cold Areas. J. Eng. Manag. 2020, 34, 69-73. 
5. Yang, Y.K.; Kim, M.Y.; Song, Y.W.; Choi, S.H.; Park, J.C. Windcatcher Louvers to Improve Ventilation Efficiency. Energies 2020, 13, 4459. [CrossRef]

6. Park, B.; Lee, S. Investigation of the Energy Saving Efficiency of a Natural Ventilation Strategy in a Multistory School Building. Energies 2020, 13, 1746. [CrossRef]

7. Fang, S. Natural Ventilation Optimization Design Research of Students' Dormitory in Wuhan Universities in Summer. Master's Thesis, Huazhong University of Science and Technology, Wuhan, China, 2012.

8. $\mathrm{Xu}, \mathrm{T}$. Indoor Air Quality Control of University Dormitory Based on Fluent Software. Master's Thesis, Shenyang Architectural University, Shenyang, China, 2018.

9. Li, Y.; Xi, J.; Wang, J.; Liang, B. Review of Research on Wind Energy Utilization Technology. SD. Chem. Ind. 2019, 48, 124-125.

10. Gao, Y.; Ma, S.; Wang, T.; Wang, T.; Gong, Y.; Peng, F.; Tsunekawa, A. Assessing the wind energy potential of China in considering its variability/intermittency. Energy Convers. Manag. 2020, 226, 113580. [CrossRef]

11. Xiao, L. Xichang Contemporary Architecture Creation Characteristics-In Public Buildings and Residential Buildings. Master's Thesis, Southwest Jiaotong University, Chengdu, China, 2013.

12. Ji, D.; Zhang, M.; Xu, T.; Wang, K.; Li, P.; Ju, F. Experimental and numerical studies of the jet tube based on venturi effect. Vacuum 2015, 111, 25-31. [CrossRef]

13. Li, M.; Bussonnière, A.; Bronson, M.; Xu, Z.; Liu, Q. Study of Venturi tube geometry on the hydrodynamic cavitation for the generation of microbubbles. Miner. Eng. 2019, 132, 268-274. [CrossRef]

14. Shi, H.; Li, M.; Nikrityuk, P.; Liu, Q. Experimental and numerical study of cavitation flows in venturi tubes: From CFD to an empirical model. Chem. Eng. Sci. 2019, 207, 672-687. [CrossRef]

15. Bimestre, T.; Júnior, J.A.M.; Botura, C.A.; Canettieri, E.V.; Tuna, C. Theoretical modeling and experimental validation of hydrodynamic cavitation reactor with a Venturi tube for sugarcane bagasse pretreatment. Bioresour. Technol. 2020, 311, 123540. [CrossRef]

16. Zhu, J.; Xie, H.; Feng, K.; Zhang, X.; Si, M. Unsteady cavitation characteristics of liquid nitrogen flows through venturi tube. Int. J. Heat Mass Transf. 2017, 112, 544-552. [CrossRef]

17. Long, X.; Zhang, J.; Wang, J.; Xu, M.; Lyu, Q.; Ji, B. Experimental investigation of the global cavitation dynamic behavior in a venturi tube with special emphasis on the cavity length variation. Int. J. Multiph. Flow 2017, 89, 290-298. [CrossRef]

18. Pérez, O.G.; Muñoz-Morales, M.; Souza, F.; Sáez, C.; Cañizares, P.; Rodrigo, M. Jet electro-absorbers for the treatment of gaseous perchloroethylene wastes. Chem. Eng. J. 2020, 395, 125096. [CrossRef]

19. Pérez, J.F.; Llanos, J.; Sáez, C.; López, C.; Cañizares, P.; Rodrigo, M.A. Electrochemical jet-cell for the in-situ generation of hydrogen peroxide. Electrochem. Commun. 2016, 71, 65-68. [CrossRef]

20. Pérez, J.F.; Llanos, J.; Sáez, C.; López, C.; Cañizares, P.; Rodrigo, M.A. The jet aerator as oxygen supplier for the electrochemical generation of H2O2. Electrochim. Acta 2017, 246, 466-474. [CrossRef]

21. Pérez, J.F.; Llanos, J.; Sáez, C.; López, C.; Cañizares, P.; Rodrigo, M.A. The pressurized jet aerator: A new aeration system for high-performance H2O2 electrolyzers. Electrochem. Commun. 2018, 89, 19-22. [CrossRef]

22. Xu, J.; Liu, X.; Pang, M. Numerical and experimental studies on transport properties of powder ejector based on double venturi effect. Vacuum 2016, 134, 92-98. [CrossRef]

23. Yu, H.; Goldsworthy, L.; Brandner, P.; Li, J.; Garaniya, V. Modelling thermal effects in cavitating high-pressure diesel sprays using an improved compressible multiphase approach. Fuel 2018, 222, 125-145. [CrossRef]

24. Lei, X.; Liao, Y.; Liao, Q. Simulation of seed motion in seed feeding device with DEM-CFD coupling approach for rapeseed and wheat. Comput. Electron. Agric. 2016, 131, 29-39. [CrossRef]

25. Quiroz-Pérez, E.; Vázquez-Román, R.; Lesso-Arroyo, R.; Barragán-Hernández, V.M. An approach to evaluate Venturi-device effects on gas wells production. J. Pet. Sci. Eng. 2014, 116, 8-18. [CrossRef]

26. Pan, Y.; Lin, R.; Liu, B. Optimal Design of the Smoke Extraction Fan Outlet Based on Venturi Effect. Ind. Safety Environ. Prot. 2018, $44,27-31$.

27. Li, X. Research on a Natural Smoke Exhaust Device Using Venturi Effect to Improve Exhaust Performance under External Wind. Master's Thesis, Chongqing University, Chongqing, China, 2019.

28. De Oliveira, M.A.; De Moraes, P.G.; De Andrade, C.L.; Bimbato, A.M.; Pereira, L.A.A. Control and Suppression of Vortex Shedding from a Slightly Rough Circular Cylinder by a Discrete Vortex Method. Energies 2020, 13, 4481. [CrossRef]

29. Shishodia, B.S.; Sanghi, S.; Mahajan, P. Computational and subjective assessment of ventilated helmet with venturi effect and backvent. Int. J. Ind. Ergon. 2018, 68, 186-198. [CrossRef]

30. Reiter, S. Assessing Wind Comfort in Urban Planning. Environ. Plan. B Plan. Des. 2010, 37, 857-873. [CrossRef]

31. Juan, Y.-H.; Wen, C.-Y.; Chen, W.-Y.; Yang, A.-S. Numerical assessments of wind power potential and installation arrangements in realistic highly urbanized areas. Renew. Sustain. Energy Rev. 2021, 135, 110165. [CrossRef]

32. Blocken, B.; Stathopoulos, T.; Carmeliet, J. Wind Environmental Conditions in Passages between Two Long Narrow Perpendicular Buildings. J. Aerosp. Eng. 2008, 21, 280-287. [CrossRef]

33. Li, B.; Luo, Z.; Sandberg, M.; Liu, J. Revisiting the 'Venturi effect' in passage ventilation between two non-parallel buildings. Build. Environ. 2015, 94, 714-722. [CrossRef]

34. Allegrini, J.; Lopez, B. The influence of angular configuration of two buildings on the local wind climate. J. Wind. Eng. Ind. Aerodyn. 2016, 156, 50-61. [CrossRef] 
35. Chong, W.T.; Wang, X.H.; Wong, K.H.; Mojumder, J.C.; Poh, S.C.; Saw, B.; Lai, S.H. Performance assessment of a hybrid solar-wind-rain eco-roof system for buildings. Energy Build. 2016, 127, 1028-1042. [CrossRef]

36. Wang, X.H.; Chong, W.T.; Wong, K.H.; Saw, L.H.; Lai, S.H.; Wang, C.-T.; Poh, S.C. The Design, Simulation and Testing of V-shape Roof Guide Vane Integrated with an Eco-roof System. Energy Procedia 2017, 105, 750-763. [CrossRef]

37. Ameer, S.A.; Chaudhry, H.N.; Agha, A. Influence of roof topology on the air distribution and ventilation effectiveness of wind towers. Energy Build. 2016, 130, 733-746. [CrossRef]

38. Blocken, B.; van Hooff, T.; Aanen, L.; Bronsema, B. Computational analysis of the performance of a venturi-shaped roof for natural ventilation: Venturi-effect versus wind-blocking effect. Comput. Fluids 2011, 48, 202-213. [CrossRef]

39. Van Hooff, T.; Blocken, B.; Aanen, L.; Bronsema, B. A venturi-shaped roof for wind-induced natural ventilation of buildings: Wind tunnel and CFD evaluation of different design configurations. Build. Environ. 2011, 46, 1797-1807. [CrossRef]

40. Van Hooff, T.; Blocken, B.; Aanen, L.; Bronsema, B. Numerical analysis of the performance of a venturi-shaped roof for natural ventilation: Influence of building width. J. Wind. Eng. Ind. Aerodyn. 2012, 104, 419-427. [CrossRef]

41. Kumar, N.; Kubota, T.; Tominaga, Y.; Shirzadi, M.; Bardhan, R. CFD simulations of wind-induced ventilation in apartment buildings with vertical voids: Effects of pilotis and wind fin on ventilation performance. Build. Environ. 2021, $194,107666$. [CrossRef]

42. Li, Z.; Zhang, H.; Wen, C.-Y.; Yang, A.-S.; Juan, Y.-H. The effects of lateral entrainment on pollutant dispersion inside a street canyon and the corresponding optimal urban design strategies. Build. Environ. 2021, 195, 107740. [CrossRef]

43. Prianto, E.; Depecker, P. Characteristics of airflow as the effect of balcony, opening design and internal division on indoor velocity: A case study of traditional dwelling in urban living quarter in tropical humid region. Energy Build. 2002, 34, 401-409. [CrossRef]

44. Prianto, E.; Depecker, P. Optimization of architectural design elements in tropical humid region with thermal comfort approach. Energy Build. 2003, 35, 273-280. [CrossRef]

45. Raja, I.A.; Nicol, J.F.; McCartney, K.J.; Humphreys, M.A. Thermal comfort: Use of controls in naturally ventilated buildings. Energy Build. 2001, 33, 235-244. [CrossRef]

46. Stavrakakis, G.; Zervas, P.; Sarimveis, H.; Markatos, N. Optimization of window-openings design for thermal comfort in naturally ventilated buildings. Appl. Math. Model. 2012, 36, 193-211. [CrossRef]

47. Muhsin, F.; Yusoff, W.F.M.; Mohamed, M.F.; Sapian, A.R. CFD modeling of natural ventilation in a void connected to the living units of multi-storey housing for thermal comfort. Energy Build. 2017, 144, 1-16. [CrossRef]

48. Wang, B.; Cot, L.; Adolphe, L.; Geoffroy, S.; Morchain, J. Estimation of wind energy over roof of two perpendicular buildings. Energy Build. 2015, 88, 57-67. [CrossRef]

49. Hughes, B.R.; Calautit, J.K.; Ghani, S. The development of commercial wind towers for natural ventilation: A review. Appl. Energy 2012, 92, 606-627. [CrossRef]

50. De Paepe, M.; Pieters, J.; Cornelis, W.M.; Gabriels, D.; Merci, B.; Demeyer, P. Airflow measurements in and around scale model cattle barns in a wind tunnel: Effect of ventilation opening height. Biosyst. Eng. 2012, 113, 22-32. [CrossRef]

51. Fan, J. Liangshan Yi Architectural Context and Its Expression in the Inheritance and Development of Modern City. Master's Thesis, Chongqing University, Chongqing, China, 2012.

52. Hou, B. The Civil Residence Architecture of Liangshan Yi and Its Architecture cultural phenomena. Master's Thesis, Chongqing University, Chongqing, China, 2004.

53. Ke, Y. A Brick Houses with Adobe Dwellings in Thermal Comfort Study. Master's Thesis, Southwest Jiaotong University, Chengdu, China, 2018.

54. EnergyPlus. Available online: https:/ / energyplus.net/ (accessed on 10 August 2020).

55. Zhang, L.; Hou, Y.; Liu, Z.; Du, J.; Xu, L.; Zhang, G.K.; Shi, L. Trombe wall for a residential building in Sichuan-Tibet alpine valley-A case study. Renew. Energy 2020, 156, 31-46. [CrossRef]

56. Potgieter, M.; Bester, C.; Bhamjee, M. Experimental and CFD investigation of a hybrid solar air heater. Sol. Energy 2020, 195, 413-428. [CrossRef] 